\title{
¿Populismo petrolero? Experiencias recientes en México y Ecuador.
}

Oil Populism? On recent experiences in Mexico and Ecuador

Rosa García Chediak

Doctora en Procesos Políticos

Contemporáneos; Becaria Postdoctoral DGPA-UNAM ; Centro de Estudios

Latinoamericanos, UNAM.

rosagarchedi@gmail.com
Fecha de recepción:

20.4.16

Fecha de aprobación:

12.8.16

\section{Resumen}

El presente texto presenta un abordaje a las determinantes clave del concepto original de populismo latinoamericano; sobre esa base discute la pertinencia de su aplicación en la época actual. Basándose en los casos de México y Ecuador y su manejo de los recursos petroleros, el artículo propone el concepto de "populismo petrolero" como subcategoría del concepto clásico. Finalmente, se destaca el modo en que las políticas petroleras de ambos países han desatado relaciones complejas con los sectores populares, donde la adhesión está lejos de ser la nota distintiva o bien prende de frágiles acomodos, mientras su participación en la política nacional -cuando acontece- más que subordinada, tiende a ser coyuntural.

Palabras clave: petróleo - populismo - populismo petrolero - clases populares - México - Ecuador

\section{Abstract}

This paper discusses some of the central features of Latin American populism according to its original enunciation, and discusses its pertinence for the analysis of political processes in current times. Focusing on the experiences of both Mexico and Ecuador and their respective management of oil resources, the concept of "oil populism" is advanced as a sub-category of the classic concept of populism. Subsequently the paper stresses how oil policies have triggered complex relations between the government 
and the popular classes in both countries, with people's support for governments is either less than a distinctive trait or relies on fragile accommodations, while their participation at the national political level -when it happens-tends to be linked to specific junctures.

Key-words: oil - populism - oil populism - popular classes - Mexico - Ecuador

\section{Introducción ${ }^{1}$}

Como es bien conocido, hoy asistimos a un resurgimiento del concepto de populismo. Al mismo se le considera adecuado para juzgar las transformaciones de una serie de países latinoamericanos, a raíz de la instauración en ellos de gobiernos catalogados como de una "nueva izquierda" por despegarse en distinta medida del programa neoliberal. Quienes suscriben el uso de la categoría populista para estos casos, por lo general reducen su capacidad explicativa a ciertas características que atribuyen a los líderes de sus gobiernos, de forma más específica, a las relaciones que han establecido con segmentos mayoritarios de población, y relacionado con lo anterior, a un tratamiento poco ortodoxo de las instituciones de la democracia representativa. Así, la mayor parte de las interpretaciones amparadas bajo este concepto arrastran no sólo un matiz peyorativo, sino además un notable empobrecimiento del concepto. La falta de solvencia del tratamiento actual del populismo es especialmente notoria si se tienen en cuenta los interesantes debates sobre el particular en el ámbito latinoamericano, desde finales de los años 50s del siglo pasado. Tal pareciera que lo acontecido en los 90s hubiera despojado de todo contenido histórico al término. Por entonces, como señalara Nicolás Lynch (2000) el calificativo de "neopopulista" se identificó exclusivamente con el uso clientelar del poder, y fue aplicado a gobiernos como el de Alberto Fujimori en Perú, Carlos Menem en Argentina, o Fernando Collor de Mello en Brasil, a pesar de su estricto apego a los programas neoliberales. Sobre este antecedente se alza el nuevo revival descafeinado del populismo, a partir del cual se esgrimen imputaciones con escaso sustento empírico.

El presente trabajo pretende en primera instancia recuperar algunas de las determinantes claves del concepto original de populismo latinoamericano. A partir de ello, se intentará un breve balance sobre cuán pertinente sería su aplicación para la época actual.A continuación se intentará un análisis más en detalle de dos países del continente latinoamericano, México y Ecuador, a fin de valorar si al menos en el manejo de los recursos petroleros se verifican características que pudieran fundamentar su clasificación como regímenes populistas en la actualidad. En esta línea de análisis se utilizará el concepto 
de populismo petrolero como una sub-categoría del concepto clásico de populismo. Por último, se examinará cómo estas políticas han desatado relaciones complejas con los sectores populares, donde la adhesión está lejos de ser la nota distintiva o bien prende de frágiles acomodos.

\section{El populismo, de lo que es a lo que fue...}

En la introducción se resumían los atributos con los que mayormente se emplea el concepto de populismo en la actualidad. De acuerdo a los objetivos de este texto, es posible considerar que buena parte del trabajo de crítica al actual revival del populismo, se encuentra adelantado. Autores como Atilio Borón (2011), con gran acierto han llamado la atención sobre el rol de determinados centros de poder norteamericanos en su reedición, así como en la acentuación de sus connotaciones negativas, ${ }^{2}$ aunque sorprende constatar que un uso similar ha sido suscrito desde variedad de posiciones ideológicas, inclusive por la izquierda radical. ${ }^{3}$ El mismo autor ha sido especialmente combativo en señalar el carácter impreciso de la reformulación emprendida por Ernesto Laclau (2005), sin dudas el teórico del populismo más citado en la actualidad. Por otra parte, encontramos revisiones de la historia del concepto que procuran un balance entre sus diferentes acepciones (Barrera, 2011;Vilas, 2011). La segunda de estas referencias, hace gala de un mérito especial: desmontar el principal argumento que se esgrime contra los regímenes considerados hoy populistas, a saber, la acusación de ser antidemocráticos por tener una relación no convencional con las instituciones de gobierno representativo. Con pulso certero, Carlos M.Vilas recoloca el debate sobre la democracia en el terreno más sustancioso de cómo son afectadas las condiciones materiales de amplios segmentos sociales, y cuáles son las relaciones de fuerzas en que se desarrollan estos regímenes. A partir de ello, el análisis de lo institucional no se sostiene como baremo exclusivo del carácter democrático. Pero en todo caso, la estrategia que se ha seleccionado para este artículo es diferente, preferimos posponer la discusión sobre la pertinencia o no de las formas de entender el populismo actualmente. En sustitución, se pondera hasta dónde se siguen verificando en la actualidad las características esenciales de los regímenes latinoamericanos que fueron originalmente identificados con el concepto de populismo.

Existe amplio consenso en ubicar los orígenes del concepto de populismo latinoamericano, en algunas experiencias particulares que comenzaron a gestarse en el continente a partir de los años 30s. En este sentido, los ejemplos por antonomasia serían el México de Lázaro Cárdenas (1934-1940), el Brasil de Getulio Vargas (1930-1945 y de 1950-1954) y la Argentina de Juan Domingo Perón (de 1946-1955 y de 1973-1974). Aunque cada uno de estos contextos tiene acentos propios y diferencias sustanciales, es posible identificar algunos rasgos fundamentales en común que les han merecido la clasificación de regímenes populistas. Para relacionar sus rasgos definitorios, se ha considerado plausible utilizar como referencia la legendaria obra de Miguel Murmis 
y Juan Carlos Portantiero, Estudios sobre los orígenes del peronismo (1971), pues aunque centrada en el examen de la situación argentina, se encuentra en diálogo con el resto de las experiencias mencionadas, y ofrece una relación precisa de lo que definió como populista al caso de estudio. Según dichas pautas, tendríamos que el populismo clásico estaría definido por:

1. Un contexto de cambio en las relaciones geopolíticas, en el cual las potencias tradicionalmente hegemónicas (Gran Bretaña o Estados Unidos) pierden buena parte de su control sobre el país.

2. Un notable crecimiento de las funciones del Estado, en particular su intervencionismo económico, que se expresa por ejemplo en el impulso a nuevas ramas de actividad económica como la industrial -para sustituir importaciones-, o haciéndose cargo de la propiedad y gestión de rubros estratégicos como la energía. 3.Una particular alianza entre las clases dominantes, en la que comienzan a ganar terreno las burguesías industriales de carácter nacional frente al dominio de las oligarquías tradicionales y hacendados terratenientes. Ante las nuevas tensiones, el Estado debe desempeñar la función de equilibrador, para conseguir cierta unidad política entre estas clases dominantes.

4. Instauración de gobiernos conformados por cuadros de extracción militar que aportan al Estado una mayor autonomía para terciar en los conflictos de intereses entre los diversos grupos de poder.

5. Un acelerado desarrollo de la clase obrera -derivado de los procesos de industrialización- que la sitúan como un actor político relevante. Por primera vez en la historia latinoamericana, al menos una parte de la movilización del sector obrero, se intenta canalizar mediante la creación de nuevos cauces institucionales que les vinculan con partidos emergentes.

6. De estas modalidades de participación resultaría la ampliación de las políticas sociales, la puesta en marcha de diversos mecanismos redistributivos, pero a la vez una cooptación importante de parte de los dirigentes populares, así como la represión de aquellos núcleos que optaron por la acción autónoma.

De los rasgos anteriormente enumerados, el desarrollo de la industria nacional destaca como un factor especialmente relevante, por el encadenamiento de efectos que le son consustanciales, en especial por la complejización de la estructura social y por las funciones igualmente complejas que demanda del Estado. Al mismo tiempo, esto nos remite al norte indiscutible que adquiere la política económica en las experiencias populistas clásicas, a saber, la promoción de la actividad industrial limitada, aquella implementada por capitales de origen nacional y mayormente orientada hacia el mercado doméstico. Desde este prisma, se hace imposible extrapolar el populismo a la contemporaneidad, cuando parece cada día más virtual hablar de economías nacionales, a medida que se afianza la globalización, con su larga secuela de internacionalización de los procesos 
de producción, y en especial, por el poder determinante que ha adquirido el capital financiero internacional en el diseño de las prioridades económicas de los Estados. Las transformaciones estructurales en curso, nos colocan por tanto en un panorama donde no cristalizan las condiciones que definieron los patrones de acumulación ni de dominación de los regímenes populistas.

No obstante, algunos aspectos de la política económica del populismo latinoamericano clásico son útiles todavía para acercarse a transformaciones que se debaten en el presente. Específicamente, parece interesante tomar como punto de referencia su modus operandi en la gestión de sectores económicos considerados estratégicos. En aquellos regímenes una de las estrategias recurrentes fue la nacionalización, procesos que tuvieron especial notoriedad en los países con hidrocarburos. En estos casos, la nacionalización implicó el reconocimiento de los recursos energéticos como propiedad de la nación -y por ende, no enajenables a particulares-, así como la creación de empresas paraestatales con autorización exclusiva $-\mathrm{O}$ al menos preferencial- para explotar estas fuentes de riqueza. La nacionalización se concibió como un mecanismo para extraer divisas y otros recursos a partir de los cuales impulsar ambiciosos programas de desarrollo económico o bienestar social. Dicho de otra manera, en esta lid se jugaba parte importante de la capacidad de maniobra de los experimentos populistas, de sus resortes para desplazar el peso de los conflictos sociales, en tanto la riqueza petrolera le permitía hacer concesiones -bajo la forma de subsidios, fideicomisos, exenciones de impuestos, fondos para programas sociales, etc.- con las que aplacar los reclamos de distintos actores, incluidos amplios sectores populares. Este último rasgo es el que se busca poner de relieve con el concepto de populismo petrolero.

Es importante acotar que la discusión que aquí se pretende no se afilia a la muy conocida corriente teórica de la "maldición de los recursos naturales", ni en su sentido más economicista según el cual la abundancia de recursos naturales tiene vínculos negativos con el crecimiento económico (Auty, 1993), ni en su prescripción de que el mismo factor genera gobiernos con déficits democráticos (Ross, 2003: 24-27). A pesar de las interesantes investigaciones producidas a partir de estos postulados, de cara a los objetivos del presente artículo se ha preferido un enfoque menos determinista. En cambio, se juzga más pertinente asumir el desenvolvimiento de las políticas petroleras como un problema de "gobernanza" (Fontaine, 2010) en el sentido de que su diseño, implementación o resultados son indisociables de los procesos políticos específicos de cada sociedad, es decir, de las conflictivas interrelaciones entre actores con diversos intereses, y de los mecanismos institucionales creados para mediar entre ellos. Bajo este prisma, se procura remarcar que más allá de las condicionantes estrictamente económico-estructurales, las políticas petroleras se desenvuelven en medio de la disputa política, cuyos acomodos terminan por expresarse en el rumbo que le confiere el Estado a la gestión del rubro. La utilización del concepto de populismo petrolero se incardina a esta perspectiva, en tanto 
asume a la política petrolera como un mecanismo de construcción de alianzas entre distintos grupos de poder, pero también extensibles a los sectores populares.

Los países aquí abordados, México y Ecuador, se implicaron en la estatalización del rubro petrolero, por caminos diferentes y con ritmos propios. Curiosamente, ambos han recibido el calificativo de populistas, aunque en distintos momentos históricos. En el caso mexicano, la experiencia nacionalizadora fue una de las vertientes que le valió fuera catalogado dentro del populismo clásico. Por su parte, Ecuador ha alcanzado dicha distinción en su versión reciente, la cual sin embargo parece privilegiar la crítica al liderazgo de Rafael Correa, y si considera el aumento de la presencia estatal en el rubro petrolero, es en tanto apéndice de ese mismo liderazgo, en su afán de generar clientelismo (De la Torre, 2010: 27). Según la relación de características generales de los regímenes populistas extraídos de la lectura de Murmis y Portantiero, en el presente ninguno de los dos casos ostentaría la imbricación de rasgos esenciales que definió al populismo latinoamericano como un fenómeno original. Por sólo mencionar dos cuestiones, no se identifica en ellos indicios de una política de industrialización por sustitución de importaciones, ${ }^{4}$ ni mucho menos un crecimiento considerable del contingente de obreros sindicalizados. ${ }^{5}$ Sin embargo, ambos países conservan todavía una mayoritaria presencia del Estado en el rubro petrolero, ${ }^{6}$ que demás se mantiene como uno de los renglones económicos más importantes. ${ }^{7}$ No obstante, las características del sector público-petrolero han experimentado en fecha reciente modificaciones en ambos países. Esta novedad invita a evaluar hasta dónde los cambios promueven una política de alianzas con los sectores populares, tendencia que señalaría no sólo la utilidad del populismo petrolero como sub-categoría, sino también la pervivencia de un modo de hacer política acuñado por el populismo clásico.

\section{La reforma energética en México y el fin de ciclo populista.}

El regreso de la presidencia de México al candidato del Partido Revolucionario Institucional (PRI) en el 2012 tuvo entre sus primeros movimientos la conciliación de intereses con el resto de los partidos mayoritarios (el Partido Acción Nacional y el Partido de la Revolución Democrática) con el fin de impulsar un paquete de reformas sintomáticamente denominadas "estructurales". Del acuerdo conocido como Pacto Por México, saldrían a la luz pública en agosto de 2013 las directrices principales del programa reformador en materia energética, a raíz de la presentación de la iniciativa presidencial al Congreso de la Unión. La punta visible del iceberg consistía en la modificación de los artículos 25, 27 y 28 constitucionales, pieza clave para permitir cambios ulteriores encaminados a ampliar todavía más la participación privada en el sector. En específico, en el primer artículo transformaba la razón social de las paraestatales PEMEX y CFE, en segunda instancia se habilitaba la celebración de contratos con particulares en para las actividades de exploración y producción petrolera (Upstream), y finalmente se liquidaba 
el monopolio estatal en diversos rubros, incluida la producción petrolera y de electricidad, algo que no había conseguido siquiera la gran crisis de la deuda externa en 1982.

Con la aprobación de las llamadas leyes secundarias en agosto de 2014, se concretaría el carácter fundamentalmente privatizador de la reforma. ${ }^{8}$ Un primer avance en este sentido fue la posibilidad abierta por la nueva Ley de Hidrocarburos, en la que se especificaban los contratos que podrían suscribirse con empresas privadas en materia de explotación y comercialización de hidrocarburos, posibilidad vedada por la Constitución hasta entonces y que literalmente finiquitó el monopolio estatal en estas materias. De acuerdo a este cambio, las empresas privadas podrán concursar en las licitaciones de bloques petroleros que promueva el Estado, y asumir directamente su exploración y explotación. Es de resaltar que bajo el amplio rótulo de "contratos", la legislación dio margen a que se incorporasen no sólo contratos de servicios, de producción o de utilidad compartida, sino además las licencias, una fórmula similar a las concesiones en tanto a efectos contables permite a las firmas privadas operar como propietarias del crudo. Para mayor controversia, se establece que la facultad de asignar los contratos recae sobre dependencias del Ejecutivo Federal (la Secretaría de Energía y la Comisión Nacional de Hidrocarburos), sin que medie supervisión legislativa alguna.

El movimiento hacia la privatización se conjuga con lo establecido en las nuevas leyes específicas que han empezado a regir sobre Petróleos de México (PEMEX) y la Comisión Federal de Electricidad (CFE). Dichas entidades fueron transformadas de "paraestatales" en "empresas productivas del Estado". En lo fundamental, esto cambia los vínculos orgánicos de estas entidades con el Estado, para asimilarlas más al modelo de empresa privada, con autonomía de gestión y presupuestal, y en suma, facilitar las asociaciones con el sector privado. En lo adelante, las empresas públicas podrán asociarse con privados para desarrollar actividades en cualquier tramo de la industria petrolera, incluida la exploración y la explotación. Por lo demás, se prevé que las nuevas leyes promuevan un incremento en estrategias de subcontratación de servicios a particulares, que ya venían desarrollando las antiguas paraestatales. Hasta aquí, las modificaciones anteriores señalan en la práctica un notable retraimiento de la propiedad estatal sobre los recursos y la actividad petrolera. En este sentido, la reforma revierte la orientación fundamental de la nacionalización de la industria de 1938.

Sin embargo, hasta el momento el nuevo marco jurídico que rige a PEMEX y la CFE no da signos de avanzar con paso inequívoco por la vía de la desregulación laboral, terreno en el cual tropieza con la influencia política del poderoso SindicatodeTrabajadores Petrolerosde la República Mexicana (STPRM).Así, el Senado al dictaminar las leyes que regirán a ambas compañías afirmó que "los derechos de los trabajadores se mantendrán en las mismas condiciones". ${ }^{9}$ No obstante, es llamativo que en el diseño de la nueva instancia directiva de las empresas, el denominado "Consejo de Administración" no 
haya incluido a ningún representante de la organización sindical. Lo anterior apunta en dirección a debilitar la figura de los convenios colectivos, intención que es propiciada por otros cambios que establecen las normativas. En especial, las nuevas leyes de PEMEX y CFE dictaminan que la Secretaría de Hacienda y Crédito Público establecerá el techo de los gastos de personal asumibles por la empresa. En virtud de lo anterior, que se suma al efecto de la caída de los precios petroleros, en el presente año, se han verificado recortes en las asignaciones presupuestarias a estas entidades, con el consiguiente despido de varios miles de trabajadores sindicalizados, ${ }^{10}$ mientras a unos 10 mil trabajadores contratados por "outsourcing" no se les renovará el contrato. ${ }^{11}$ En conclusión, por esta vía sí se avizora un cambio significativo tendiente al debilitamiento de las relaciones que hasta entonces había mantenido el Estado mexicano con uno de los pocos sectores sindicalizados que todavía conservaba gran influencia política.

Por otra parte, tampoco la normativa reglamentaria de las nuevas empresas, ni la nueva Ley de Ingresos sobre Hidrocarburos, han despejado el problema de la carga fiscal excesiva que por tradición ha lastrado el desarrollo, en especial el de PEMEX. ${ }^{12}$ Lo anterior hace peligrar la supervivencia de la empresa pública, dada la apertura a la competencia que promueve la reforma. ${ }^{13}$ Es remarcable que PEMEX esté abocada así a un círculo vicioso, en el cual deberá seguir contribuyendo con cantidades importantes al presupuesto del Estado pero a costa de su propia supervivencia, sin poder modernizarse y, a la postre, con menor capacidad de contribuir a las finanzas públicas. Esta cadena de efectos ha venido a ser complicada por el declive de las cotizaciones petroleras, que impactan directamente sobre los ingresos obtenidos por PEMEX. Ante esta depresión de los precios, y aunque el gobierno ha declarado que estar en vías de compensar sus efectos a través de reformas tributarias que han redundado en una mayor recaudación, se prevé que el presupuesto a negociar para el año 2016 ostentará recortes significativos. ${ }^{14}$ Por tradición, la reducción del gasto público redundará por una parte en menores inversiones productivas -por ejemplo las destinadas a la propia modernización de PEMEX $-{ }^{15}$ y por la otra, en menor gasto social en áreas prioritarias como salud, educación y seguridad social. ${ }^{16}$ Esta misma lógica se aplica a la CFE; en este caso las nuevas exigencias de competitividad amenazan a los tradicionales subsidios a los usuarios domésticos, por el peso de los mismos en los balances contables. De esta manera, es evidente que ya no serán posibles los equilibrios sociales que otrora permitía una política fiscal fincada en el control de la riqueza petrolera.

Lo anteriormente descrito sería suficiente para afirmar que la nueva política energética llevada a cabo por el gobierno mexicano se aleja del modus operandi del populismo clásico. Se trata de transformaciones que no procuran afirmar la primacía del sector público, al tiempo que debilitan los vínculos con importantes sectores sindicales. Tampoco se observa que los cambios promuevan la inversión pública en aras de potenciar otras ramas de actividad económica nacional ni que den nuevos aires a los programas de 
redistribución social. Todo esto por no mencionar la importancia que ha tenido la hegemonía estadounidense en el diseño de la reforma. ${ }^{17}$ Según lo examinado, podría pensarse que en realidad la reforma mexicana ha sido la sentencia de muerte de uno de los últimos vestigios del populismo de otros tiempos. Para añadir una raya más al tigre, la reforma ha tenido una amplia desaprobación popular.

A fin de comprender la envergadura de la reacción a la reforma energética en México, es preciso considerar la impronta de expropiación petrolera de 1938 y su peso gravitacional dentro del discurso nacionalista del populismo mexicano, por más de siete décadas. Lo anterior, sumado a una ponderación de los principales efectos de estos cambios, determinó que tan pronto como trascendieron a la luz pública las directrices esenciales de la reforma, comenzaron a generarse numerosas movilizaciones y campañas de opinión críticas. Así, durante el último cuatrimestre de 2013, México y especialmente su capital vivieron importantes protestas contra las modificaciones constitucionales, por entonces negociándose en las Cámaras. Las manifestaciones tuvieron por móvil común, un extendido sentimiento acerca del proyecto reformador que se orientaba hacia el despojo del patrimonio nacional. Las acciones de mayor envergadura fueron convocadas por el líder político Andrés Manuel López Obrador de la agrupación MORENA. Estas abarcaron cercos en torno a las sedes de las cámaras de Diputados y Senadores, protestas ante diversos congresos locales, o las marchas al Zócalo. ${ }^{18}$ Es de resaltar que estas últimas contaron con el empuje de diversos sindicatos, aspecto clave para dotarlas de mayor magnitud. ${ }^{19}$ Aunque más tardíamente, el Partido de la Revolución de Democrática (PRD) también realizó llamamientos a manifestar la desaprobación de la reforma en las calles, con algunas marchas significativas en los primeros meses de 2014. Por otra parte, la negociación de la reforma originó un profundo debate, en el cual destacaron una serie de campañas de opinión avanzadas por asociaciones de perfil profesional. ${ }^{20}$ Finalmente, la amplia desaprobación que suscitó la reforma, motivó dos intentos por someter estos cambios a consulta popular. Concretamente, el Partido de la Revolución Democrática (PRD) y el político Andrés Manuel Obrador recabaron cada uno más de 2 millones de firmas para presentar sendas solicitudes de consulta. ${ }^{21}$ Ambas iniciativas se vieron no obstante truncadas por la resolución de improcedencia que emitió la Suprema Corte de Justicia de la Nación (SCJN), con base en las limitaciones constitucionales y legales establecidas para la figura de la consulta popular en el país.

Los ejemplos antes señalados ponen en evidencia la escasa popularidad de la reforma. Pero las posibilidades de acercamiento del Estado a los sectores populares se vieron dinamitadas también desde otros frentes más específicos, como fue el rechazo a las eventuales repercusiones de la reforma sobre cuestiones ambientales o de derechos humanos. En cuanto a lo primero, causó gran revuelo la puerta abierta por la legislación secundaria a la explotación de hidrocarburos no convencionales mediante la fractura hidráulica. ${ }^{22}$ De hecho, a medida que avanzaban las negociaciones de la reforma, se fue 
configurando la "Alianza Mexicana contra el Fracking”, red de asociaciones civiles que se ha mantenido presionando a los legisladores a fin de hacer avanzar una ley específica para la prohibición del fracking. ${ }^{23}$ En otra línea, se han producido igualmente acciones contrarias a la reforma, por considerar que la aplicación de la misma amenaza los derechos humanos de determinados colectivos, especialmente pueblos originarios y comunidades campesinas. Aunque se ha hecho recurrente la práctica de las expropiaciones sin que medien mecanismos de consulta previa a los vecinos afectados por grandes proyectos de infraestructura, el armazón legal de la reforma provee amparo a este tipo de proceder. Por estas razones, organizaciones civiles solicitaron una audiencia a la Comisión Interamericana de Derechos Humanos (CIDH), a fin de que esta instancia se pronuncie sobre las violaciones a los derechos humanos que supone la nueva política energética. ${ }^{24}$

Hasta este punto, la reforma energética mexicana nos remite a un escenario donde no sólo se esfuma uno de los últimos restos del populismo de otra época. Al mismo tiempo, se inaugura una época en la cual el sector energético lejos de posicionarse como plataforma desde la cual tejer diversas alianzas con los sectores populares, se erige como un nuevo surtidero de conflictos. La nueva coyuntura abierta por el declive de los precios internacionales del petróleo, opera ya como una suerte de catálisis en la cual los efectos impopulares de la reforma no harán sino agravarse.

\section{La reinterpretación ecuatoriana de una agenda clásica.}

En el caso de Ecuador, los recientes cambios en la política energética parecen guardar una coincidencia al menos puntual con el populismo petrolero, dada por la tendencia hacia la afirmación del rol preponderante del sector público. El Decreto 662 de 2007 puede interpretarse como un primer movimiento al respecto; por su intermedio se elevó al 99\% la participación del Estado en las ganancias extraordinarias obtenidas por las compañías privadas dada el alza de los precios del hidrocarburo. La medida formaba parte de una estrategia más ambiciosa orientada a conseguir fórmulas contractuales más ventajosas para el erario público, orientación que sería desarrollada en los años posteriores. Por otra parte, la promulgación de la nueva Constitución en 2008 refrendó en diversos artículos (313-317) el carácter estratégico del sector energético, a partir de lo cual el Estado se reservó su control y gestión, en un giro que sentó las bases para promover el rol de las empresas públicas. Otra línea distintiva que desde sus inicios llevó adelante la presidencia de Rafael Correa, fue acrecentar el traspaso a empresas controladas por el Estado de bloques petroleros claves que hasta el momento habían sido explotados por corporaciones privadas (Ruiz e Iturralde, 2013: 102). Aunque el inicio de estos traspasos se fijaba en la administración de Alfredo Palacio (2005-2007), lo cierto es que el nuevo gobierno imprimió mayor energía a esta tendencia, pero al mismo tiempo experimentó en la búsqueda de modelos de gestión empresarial que solucionaran algunos dilemas que confrontaba la paraestatal Petroecuador. En este contexto, se constituyó en 2008 
la empresa Petroamazonas S.A. como filial de la paraestatal Petroecuador, con el fin de asumir la explotación del bloque 15 (20-30 millones de barriles de petróleo anuales), que hasta entonces había sido operado por la compañía estadounidense Occidental y cuyo contrato había sido rescindido por la anterior administración presidencial.

Sobre estos antecedentes, en 2010 tuvo lugar la transformación de mayor envergadura para el sector, al promulgarse la nueva Ley de Hidrocarburos que impuso la renegociación de los contratos petroleros a diversas compañías trasnacionales. ${ }^{25}$ La migración a los nuevos moldes contractuales buscó revertir el anterior predominio de los "contratos de participación" que habían proliferado desde inicios de los 90s, período de mayor liberalización dentro del sector. Los mismos conferían al Estado una participación minoritaria en los volúmenes de producción -en torno al 25\%-, ${ }^{26}$ reduciendo los ingresos petroleros percibidos por el fisco.En contrapartida, con la reformulación de la ley en 2010, la acción estatal estuvo encaminada a reafirmar su control sobre el primer eslabón de la cadena productiva (Upstream), así como mejorar su participación en la renta petrolera. A tales fines, se generalizó la figura del contrato de prestación de servicios, modalidad pensada para reafirmar la propiedad del Estado sobre el petróleo y aprovechar una eventual subida de los precios, en tanto fija una tarifa a partir de la cual se le cancela a las petroleras privadas el pago por sus servicios. ${ }^{27}$ Como resultado de aquella renegociación, la producción a cargo de las empresas públicas aumentó significativamente, ${ }^{28}$ al igual que los ingresos percibidos por el Estado. ${ }^{29} \mathrm{Un}$ aspecto a tener en cuenta es que la renegociación de los contratos, en tanto presupone asociaciones con las petroleras privadas, significa una apuesta por el sector público moderada, si se compara con el populismo petrolero clásico, que conllevó expropiaciones y la creación de empresas estatales con capacidad operativa suficiente para mantener el control monopólico sobre la exploración-producción de crudo, más el proyecto de edificar un sector empresarial público que abarcara las industrias y actividades conexas (eléctrica, refinación de combustibles, derivados plásticos, transporte, suministros industriales, etc...). Adicionalmente, la renegociación de los contratos dejaba algunas interrogantes en el aire. En especial existían serias dudas sobre la viabilidad de los acuerdos para un contexto de precios bajos.

En todo caso las reformas a la normativa petrolera emprendidas en 2010, se acercaban al programa populista también desde otra vertiente, la de los fines redistributivos que subyacen a la intención de mejorar la participación estatal en la renta petrolera. En esta línea, la citada reforma de la Ley de Hidrocarburos estableció que el 3\% de las utilidades deben repartirse entre los trabajadores del sector, mientras un 12\% se entregará al Estado, que a su vez asume la obligación de invertirlo en proyectos sociales (salud y educación), distribuyéndolo equitativamente a los gobiernos locales de las áreas afectadas por la actividad hidrocarburífera. Esta precisión ha sido crucial en el respaldo que ha cosechado el partido gobernante en algunas comunidades amazónicas, como se verá. Pero más allá de estas derivadas más o menos locales y acotadas, para sopesar si lo recaudado por 
el petróleo deriva hacia políticas redistributivas capaces de procurarle al gobierno un apoyo mayoritario de los sectores populares a nivel nacional, merece la pena asumir una perspectiva más amplia.

Antes de proseguir, debe tenerse en cuenta que a partir la aprobación de la Ley Orgánica para la Recuperación del Uso de los Recursos Petroleros del Estado y Racionalización Administrativa de los Procesos de Endeudamiento (2008), en Ecuador se eliminaron las diferentes preasignaciones petroleras, y los ingresos del sector pasaron directamente al gobierno central (Orozco, 2014: 50-51), representando alrededor de la tercera parte del total de los ingresos del sector público. Siendo así prácticamente imposible determinar el destino específico de los recursos petroleros, no queda otra alternativa que examinar si el aumento de los recursos fiscales en su totalidad, ha ido de la mano de un aumento del gasto público, y cuál ha sido el destino de los egresos, estrategia que permite de igual modo identificar si existen mecanismos de redistribución.

Con base en distintas fuentes de información, es posible sostener que en efecto la avidez del Estado por aumentar los recursos fiscales, ha estado acompañada de un aumento sostenido del gasto público, ${ }^{30}$ el cual denota tres grandes prioridades: la inversión en infraestructuras, la expansión del crédito y el gasto social (Ruiz e Iturralde, 2013: 92), desplazando considerablemente la prelación que tuvo el pago del servicio de la deuda en los gobiernos anteriores. Pero centrándonos en los mecanismos de redistribución, sin considerar el comportamiento de las variables salariales, ${ }^{31}$ el ámbito donde mejor puede evaluarse es el aumento del gasto social. ${ }^{32} \mathrm{El}$ crecimiento de estas partidas ha derivado en un sustantivo incremento en el acceso a los servicios sociales de bienestar, así como de las transferencias de efectivo, tanto contributivas (seguridad social) como no contributivas (Bono de Desarrollo Humano), según lo documenta la investigación de Analía Minteguiaga y Gemma Ubasart-González (2014). Al margen de estos servicios y transferencias que conforman el gasto específicamente social, otro renglón importante a considerar son los subsidios, especialmente los aplicables al consumo de combustibles, que representan más del 50\% del total de los subsidios. Un caso ilustrativo de la importancia para el bienestar de estos los subsidios resulta el que se aplica al consumo de gas licuado de petróleo (GLP) no sólo por la magnitud del mismo (un 70\% del valor de mercado) sino por ser el que se utiliza masivamente en los hogares. Aunque la Revolución Ciudadana ${ }^{33}$ heredó este patrón de gasto, parte considerable de los sectores populares lo perciben como una conquista de las luchas contra la austeridad neoliberal. Amparado en ese imaginario, el gobierno ecuatoriano ha aumentado significativamente los montos de esta partida, ${ }^{34}$ mientras procura invertir en la generación de energía hidroeléctrica que permita efectuar una transición en el consumo y aliviar la carga presupuestaria.

En conclusión, este brevísimo análisis del esfuerzo redistribuidor, nos permite coincidir con el investigador Pablo Ospina Peralta (2015) para quien el creciente gasto público 
-con importantes resultados en la disminución de la pobreza y la desigualdad- junto con los distintos mecanismos de estimulación al consumo, le habían procurado al gobierno un respaldo mayoritario.Estos apoyos ahora muestran un retraimiento debido al drástico declivede las cotizaciones petroleras. De forma llamativa, se ha llegado a plantear que estos desgajamientos denotan una ruptura de los "pactos de consumo", 35 a fin de destacar el peso que tiene la desaprobación de las clases medias, hasta entonces aupadas por las políticas gubernamentales. La crisis económica, agravada por los efectos de la apreciación del dólar, ha quitado impulso a las políticas de inversión y de fomento al consumo, lo cual se considera el trasfondo de las protestas vividas en el Ecuador durante el verano de 2015, detonadas en primera instancia contra la reforma a la Ley de Herencias y Plusvalía (Peralta 2015). La veloz transmisión de la crisis sobre el tejido social, demuestra una fragilidad que hace pensar que el gobierno no ha logrado cristalizar su entramado de alianzas, y en sentido conexo, fundamentar su hegemonía mediante la socialización de discursos y valores afinesa su proyecto político. Un déficit de esta naturaleza es un elemento adicional que desaconseja el asignar el rótulo de populismo petrolero a la experiencia ecuatoriana.

Volviendo sobre los cambios implementados en el sector petrolero por la administración de Rafael Correa, existe un último aspecto que problematiza calificarle como una experiencia de populismo petrolero. Se trata de la rearticulación de las relaciones del Estado con el sindicalismo petrolero de las empresas públicas, que de forma resumida ha pasado por una etapa de destrucción y otra de reconstrucción. ${ }^{36}$ En sentido estricto, desde sus primeros pasos la Revolución Ciudadana entabló una relación tensa con organizaciones sindicales ya veteranas como la Federación Nacional de Trabajadores de Petroecuador (FETRAPEC), las cuales ostentaban cierto desgaste al momento de ascender el nuevo gobierno. ${ }^{37}$ Aunque la tesis oficial sobre la necesidad de desmantelar a una serie de sindicatos históricos se afianza en los privilegios desproporcionados y las tramas clientelares que los mismos manejaban, ${ }^{38}$ debe de igual modo reconocerse que las acciones de la nueva fuerza política comandada por el partido Alianza País, han creado sobresaltos por avanzar en detrimento de los derechos laborales, especialmente en el sector público. ${ }^{39}$

En el caso específico de la FETRAPEC, uno de los sindicatos más poderosos del país, desde el primer momento se trató de un enfrentamiento abierto, como lo atestigua la orden de que la Marina interviniera la administración de PETROECUADOR en 2008 -por entonces empresa paraestatal- con el consiguiente descabezamiento de su cúpula sindical (Marega, 2015: 38). Con posterioridad, la Ley Orgánica de Empresas Públicas (la LOEP de 2009) y la Ley Orgánica del Servicio Público (la LOSEP de 2010), si bien no exclusivamente dirigidas al sector petrolero, sí contribuyeron a debilitar aún más a este tipo de sindicalismo, al establecer que el grueso de los trabajadores del sector público serían catalogados como "servidores" y en consecuencia pasarían a estar regulados 
por la LOSEP, lo cual implicaba la eliminación del derecho a sindicalización, a la contratación colectiva y a la huelga. Pero sin dudas el tiro de gracia para el sindicalismo petrolero histórico estuvo dado por la transformación de Petroamazonas S.A y de la paraestatal Petroecuador en empresas públicas por medio de los Decretos 314 y 315 de 2010 que se fundamentaban en la LOEP. En las nuevas empresas públicas, quedó eliminada la representación de los sindicatos en su máxima instancia administrativa, ahora denominadas Gerencias Generales. Con ello se cortó de tajo la posibilidad de que representantes sindicales participaran en el diseño de las políticas empresariales y mucho menos que incursionaran en los debates sobre la política petrolera nacional, como había sucedido previamente (Marega, 2015: 38). Además, como los decretos ordenaron una integración de las distintas filiales que componían a las empresas, terminaron por elevarse los requisitos numéricos para constituir comités de empresa y sindicatos, al tiempo que la estructura sindical se centralizaba, perdiendo comités locales que le habían permitido sostener su presencia a nivel nacional (íd. pág.39).

Otra estrategia paralela para debilitar el sindicalismo petrolero puede considerarse el estímulo a la "tercerización" o subcontratación de personal, posibilidad que no fue cancelada mediante los mandatos constitucionales derivados de la Asamblea Constituyente en 2007, específicamente el No.8. En este sentido, se observa con cautela la reestructuración empresarial acontecida en 2013, en virtud de la cual Petroamazonas E.P. asumió todas las actividades de exploración y explotación que desempeñaba Petroecuador E.P., que a su vez fue desplazada sólo al área de exportaciones, refinerías y oleoductos. Sobre Petroamazonas, desde sus tiempos de sociedad anónima, pesan las acusaciones de haber promovido la "tercerización" dentro del sector petrolero.

Hasta aquí parecería que estamos en presencia de una simple estrategia de desmantelamiento de las organizaciones sindicales. Sin embargo, es preciso reconocer en paralelo una reestructuración sindical promovida también por el Estado, proceso típico de un repertorio populista clásico, pero interpretado ahora en una versión de bajo perfil. En este sentido, ya desde la Constitución aprobada en 2008, se establecía (Art. 326) que el Estado promovería la creación de organizaciones sindicales así como su "funcionamiento democrático". En consonancia, no resulta extraño que a los pocos días de anunciarse el cambio de razón social de la petrolera estatal, se formara el Sindicato Nacional de la Empresa Pública EP PETROECUADOR, donde se aglutinaron obreros y dirigentes que simpatizaban con el gobierno (Marega, 2015: 39). Otro ejemplo citado en la misma investigación sería el Comité de Empresa de los trabajadores de la EP PETROECUADOR (CETRAPEP) constituido en mayo de 2013. La creación de la Central Unitaria de Trabajadores (CUT) en noviembre de 2014, a la que se han integrado los restos de la FETRAPEC, constituye un nuevo paso en este sentido de afianzar un tejido sindical articulado con las prioridades del gobierno, proceso que marcha a paso lento sin que puedan discernirse hasta la fecha signos evidentes de corporativización..$^{40}$ En todo caso, 
esta evidente reconstrucción del tejido sindical no implica que las nuevas organizaciones actúen como una simple correa de transmisión. Como ya se observa, estos actores han aprovechado la circunstancia para trasladar al seno del Estado demandas puntuales de los trabajadores del sector público. ${ }^{41}$

En cualquier caso, es preciso reconocer que en la pretensión de hegemonizar al movimiento obrero, el Estado ecuatoriano tiene mucho camino por delante, como lo demuestra la convocatoria a un Paro Nacional el 13 de agosto de 2015. Por otra parte, la estructura del empleo ecuatoriano tampoco permite que el movimiento sindical se transforme en un actor político de primera línea. Condicionan este resultado, factores como el predominio de empresas con pocos empleados, ${ }^{42}$ el alto porcentaje del empleo informal, así como la poca representatividad que tienen los trabajadores industriales o del sector del transporte, es decir, aquellos de mayor potencial movilizador. ${ }^{43}$

Para concluir, quedaría la interrogante de si la política petrolera reciente ha servido para generar alianzas con los movimientos sociales gestados en la resistencia al neoliberalismo durante la década de 1990. Para ilustrar que en este terreno están lejos de verificarse acuerdos sólidos, quizá el mejor ejemplo sean los conflictos que han enfrentado al gobierno de la Revolución Ciudadana con las organizaciones indígenas más representativas, así como con no pocos voceros del ecologismo ecuatoriano. Si bien durante su estreno presidencial, el actual mandatario ecuatoriano contó con el apoyo de parte importante de los ecologistas, no se afirma lo mismo con respecto a las organizaciones indígenas, respecto a las cuales desde los inicios la tensión "se mantuvo constante" (Ramírez, 2010: 41). Aunque cada uno de estos movimientos ha tenido sus desencuentros con el gobierno sobre temas específicos, desde fecha tan temprana como el 2009 , se han enfrentado de consuno a la política de fomentar la minería en gran escala, y también a concesiones petroleras en determinados territorios.

Dentro del período presidencial vigente, la ruptura más importante al respecto se originó en 2013, a raíz de que el Ejecutivo ecuatoriano tomara la decisión de finiquitar la "Iniciativa Yasuní-ITT" y comenzara a explotar campos petroleros que se intersectan con el Parque Nacional delYasuní. El tema desató una significativa reacción por tratarse de una zona de alta biodiversidad y además hogar de tribus que viven en aislamiento voluntario. Representantes de organizaciones ecologistas como el Frente de Defensa de la Amazonía, Acción Ecológica o el Centro de Derechos Económicos y Sociales, junto con la Confederación de Nacionalidades Indígenas del Ecuador (CONIAE) y la Confederación de Nacionalidades Kichwas del Ecuador (ECUARUNARI), sumaron sus esfuerzos a los del colectivo Yasunidos. En este sentido, apoyaron su iniciativa de solicitar una consulta popular sobre el tema en abril de 2014, la cual con gran celeridad fue desestimada por el Consejo Nacional Electoral (CNE), al declarar inválidas más de la mitad de las más de 750.000 firmas presentadas. ${ }^{44}$ La negativa- impugnada por los 
promotores de la solicitud- terminó de profundizar el divorcio entre la dirección del Estado ecuatoriano y sectores considerables del movimiento indígena y ecologista, ${ }^{45}$ drama que no ha cesado de agravarse y que continúa teniendo en la política petrolera un punto de divergencias. ${ }^{46}$

A modo de balance, las modificaciones que en materia energética ha llevado adelante el gobierno de Rafael Correa, no satisfacen aspectos cardinales de lo que pudiera ser la "hoja de ruta" clásica del populismo latinoamericano. En primer lugar, no es posible concluir que se estén impulsando otras ramas del aparato productivo como la industrial y mucho menos que se haya logrado avanzar en la sustitución de importaciones. ${ }^{47} \mathrm{~A}$ propósito de lo anterior, resulta más bien recurrente que se acuse a la política económica de reforzar el enraizamiento en un modelo tradicionalmente "extractivista" o "primario-exportador" que no genera encadenamientos productivos, salvo en nichos de la actividad agroindustrial (Cypher y Alfaro, 2015: 171) -una rama muy vinculada, de acuerdo a algunas opiniones, a los grandes propietarios terratenientes y élites conservadoras del país (Herrera-Revelo, 2016). Tampoco han cristalizado las intenciones del gobierno ecuatoriano sobre un nuevo mapa en sus relaciones internacionales. ${ }^{48} \mathrm{~A}$ nivel sub-categorial, si bien el experimento de la Revolución Ciudadana se acerca en algunos puntos del populismo petrolero (afianzamiento del sector público en el sector, mecanismos de redistribución y reconstrucción de un tejido sindical afín), ostenta déficits que impiden asignarle este calificativo. Por ejemplo, no es posible afirmar que la política petrolera del gobierno ecuatoriano se encamine hacia nuevos mecanismos de corporativismo sindical. Del mismo modo, la política petrolera se encuentra lejos de facilitar alianzas con los movimientos populares de mayor importancia en el Ecuador. Por el contrario, las fracturas con organizaciones indigenistas y de defensa del medio ambiente, han tenido como manzana de la discordia justamente decisiones en estas materias.

\section{¿Malos tiempos para un "populismo" fincado en el petróleo?}

De acuerdo a la línea argumental aquí sostenida, a pesar del entusiasmo actual por endilgarle el rótulo de "populistas" a un grupo de gobiernos latinoamericanos, el uso del término parece poco justificado, especialmente si se tienen en cuenta las características objetivas que alimentaron el uso original del concepto en la América Latina desde los años treinta. Sin considerar tales condiciones, el término hoy se reserva para describir a gabinetes que no se ajustan a un estricto programa neoliberal y/o desarrollan un manejo poco convencional de la democracia representativa.

Al retomar el concepto clásico de populismo, el análisis de las políticas energéticas parece un buen acicate desde el cual establecer hasta dónde presenciamos tiempos adversos para un revival populista. Lo revisado para dos de los más importantes países petroleros de la región -que en distintos momentos han recibido el apelativo de "populistas- nos permite poner algunas ideas en claro. 
En el caso de la reforma energética que comenzó a realizarse en México desde mediados de 2013, todo apunta a una acción estatal conscientemente orientada a barrer los remanentes del populismo abonado en otra época. En este sentido, el notable adelgazamiento del sector público en el rubro, que amenaza ahora con reducir al máximo la capacidad operativa de PEMEX y la CFE, parece una evidencia sólida. Como se ha comentado, los cambios en cuestión tendrán efectos directos para el fisco mexicano, a cuyas consecuencias negativas se agregan ahora los vendavales originados por el declive de los precios petroleros. Así, la nueva arquitectura de la política energética mexicana recorta cada vez más las posibilidades de establecer alianzas con diversos sectores populares, e incluso llega a afectar a organizaciones sindicales largamente consolidadas en las negociaciones corporativas con el Estado, como el Sindicato de Trabajadores Petroleros de la República Mexicana (STPRM). Las nutridas protestas que se vivieron en México de forma previa a la aprobación legislativa de la reforma no son sino el anticipo de una ruptura irreversible de los pactos sociales sustentados en la riqueza petrolera del país.

En sentido contrario, a raíz de la investidura presidencial de Rafael Correa en el Ecuador, el país ha presenciado políticas energéticas que pudieran guardar algún parecido con el populismo petrolero. Es de remarcar que parte importante de la legitimidad cosechada por el gobierno se ha sustentado sobre las posibilidades derivadas de los cambios en el sector energético, especialmente por una mayor captación estatal de los ingresos petroleros. Aun así, no resulta pertinente calificar como populista a las políticas energéticas ecuatorianas. Un primer elemento en este sentido es su falta de congruencia con otros aspectos de lo que sería la política económica inherente al populismo de la década de 1930. En especial el estancamiento de la actividad industrial es un aspecto crítico, no sólo por sus implicaciones económicas sino porque de ello se derivaría la conformación de una estructura social sin la cual es imposible se den los pactos propios del populismo. Pero incluso si se analiza la realidad de los sectores populares y de sus movimientos más significativos en el Ecuador de hoy, lo que se observa es que las políticas energéticas lejos de propiciar acuerdos, lo que han originado son profundos desencuentros de estos con el gobierno de la Revolución Ciudadana.

A partir de los argumentos esgrimidos, parece fundamentado afirmar que no vivimos hoy los mejores tiempos para una reedición del populismo en general, ni siquiera de los pactos políticos propios del populismo petrolero. Por mucho que el calificativo goce de una notoria celebridad, las tendencias estructurales y las correlaciones de fuerzas del presente no tienen mucho que ver con aquellas del pasado populista latinoamericano. La tendencia es confirmada por el análisis específico de las políticas petroleras de México y Ecuador. $\mathrm{Al}$ respecto, entre estos países puede trazarse una escala donde el mínimo estaría dado por una marcada liberalización del sector y el máximo por un intento de mayor regulación estatal pero sin pretensiones monopólicas. En cuanto a cómo se gestionan las alianzas con los sectores populares, se observa bien una actitud de desdén (México) o bien la apuesta de 
confiar en la legitimidad producida por un aumento del gasto público, a su vez alimentada por la bonanza petrolera (Ecuador). Ante este panorama, la participación de los sectores populares en el rumbo de las políticas gubernamentales, no es que tenga carácter subordinado -algo propio de los regímenes populistas clásicos- sino que tiende a producirse -en el mejor de los casos- de forma coyuntural. 
${ }^{1}$ El presente trabajo es resultado del proyecto de investigación Estado, políticas públicas y cultura política: México y Ecuador durante el último trienio, financiado por el Programa de Becas Postdoctorales DGPA/UNAM.

${ }^{2}$ Precisa este sociólogo argentino el papel desempeñado por el gobierno norteamericano en la época del tándem George Bush-Condolezza Rice, y su uso del término para sancionar a los gobiernos de Venezuela, Bolivia y Ecuador, los cuales han llevado adelante políticas ajenas al canon neoliberal, con determinados acentos nacionalistas y redistribuidores.

${ }^{3}$ En la actualidad encontramos incluso intelectuales afines a los movimientos sociales anti-neoliberales, que utilizan esta interpretación del populismo para dirigirse a las mismas experiencias. Un caso especialmente emblemático en Maristella Svampa (2015).

${ }^{4}$ Aunque México resulta un país destacable a nivel regional por la magnitud de su industria, encontramos que se trata de una actividad fuertemente integrada en circuitos productivos internacionales. En este sentido, aun cuando el país se ha encaminado hacia el predominio de las exportaciones no petroleras (cerca del $90 \%$ del total según reportes del Banco de México para el 2014, ver:http://www.banxico.org.mx/SieInternet/consultarDirectorioInternetAction.do?accion $=$ consultarCuad Analitico\&idCuad ro $=$ CA176\&sector $=1 \&$ locale $=\mathrm{es}$ con acceso 3-09-2015) y aun cuando los bienes manufacturados representen el $95 \%$ de este tipo de exportaciones, debe tenerse en cuenta que más de la mitad de estas manufacturas son producidas en maquilas, de acuerdo a estimaciones del economista Rolando Cordera para 2013.

Por su parte, Ecuador da señales de dirigirse por la senda del extractivismo, potenciando las exportaciones petroleras como principal renglón económico. Lo anterior se demuestra al analizar los datos de la Balanza Comercial ecuatoriana. Según reportes del Banco Central del Ecuador (ver: contenido.bce.fin.ec/documentos/PublicacionesNotas/Catalogo/IEMensual/m1961/IEM-322.xls con acceso 3-09-2015). De 2010 a 2014 se percibe un incremento similar del volumen de exportación e importación, sin embargo las cifras de la balanza específicamente petrolera denotan que el país mantiene un saldo positivo a favor de las exportaciones. Si se examina la balanza comercial no petrolera, se observará que las importaciones no-petroleras resultan con diferencia las más dinámicas. Por otra parte, según las estadísticas publicadas por el Ministerio de Comercio Exterior del Ecuador en el 2013, las exportaciones de bienes industriales se acercaron a los 5 mil millones de dólares, mientras que las de productos primarios las cuadriplicaron al sumar más de 20 mil millones de dólares. Estadística disponible en: http://www.comercioexterior.gob.ec/exportaciones-1/ con acceso 25-08-2018.

${ }^{5}$ Se estima que la tasa de afiliación sindical rondaba el 8.8\% en México en 2012 (Bensusán y Middlebrook, 2013: 56). En Ecuador, la tasa de afiliación sería del 4.8\%, si se toman por válidas las declaraciones del presidente Rafael Correa en el Mensaje a la Nación del 24 de Mayo de 2015, en el cual refiere la existencia de 370.000 trabajadores sindicalizados (Ver: http://ecuadoryacambio.ec/mensaje-a-la-nacion-2015-presidente-rafael-correa/ con acceso 3-09-2015), que se divide por la población económicamente activa (7.734 mil, según el reporte del INEC disponible enhttp://www.ecuadorencifras.gob.ec/documentos/web-inec/ EMPLEO/2015/Marzo-2015/Informe_Eje cutivo_Mar15.pdf con acceso 3-09-2015).

${ }^{6}$ Hasta la realización de la primera etapa de la -poco exitosa- Ronda Uno el pasado 15 de julio de 2015, la explotación del petróleo mexicano era competencia prácticamente exclusiva de la empresa pública PEMEX, cuya capacidad productiva oscila desde los últimos 10 años en torno a los 2.5 de millones de barriles/ día. En Ecuador, cifras del Banco Central de Ecuador, disponibles desde http://www.bce.fin.ec/index.php/hidrocarburos con acceso 6-08-2015, contabilizaban que a enero de 2015 la producción petrolera a cargo de compañías públicas representaba el $77 \%$ del total, si bien asociadas mediante distintos contratos a petroleras privadas. La producción promedio en el país gira en torno a los 500 mil barriles/día.

${ }^{7}$ Según estimaciones del Banco Mundial, las rentas obtenidas por México a partir de la venta de petróleo en 2013 representaron alrededor del 6\% de su PIB (porcentaje que hace una década se situaba en torno al 10\%), mientras que en Ecuador este factor superó el 16\% del PIB.Ver: http://datos.bancomundial.org/indicador/ NY.GDP.PETR.RT.ZS con acceso 3-09-2015.

${ }^{8}$ La relación de las leyes aprobadas se encuentra disponible en http://www.energia.gob.mx/webSener/ leyes_Secundarias/

${ }_{9}^{9}$ Ver http://www.animalpolitico.com/2014/07/el-senado-aprueba-que-pemex-y-la-cfe-se-conviertan-enempresas-productivas-del-estado/ con acceso 18-06-2015.

10 Ver (http://www.sdpnoticias.com/nacional/2015/03/04/trabajadores-de-pemex-protestaran-el-18-demarzo-por-despidoscon acceso 18-06-2015.

${ }^{11}$ Se estima que los trabajadores subcontratados por ambas entidades suman entre un 20 y un $30 \%$ de estas plantillas. Noticias sobre los despidos en http://www.elfinanciero.com.mx/economia/pemex-se-despide-alpersonal-de-outsourcing-por-austeridad.htmlcon acceso 18-06-2015. 
${ }^{12}$ Debe señalarse que el petróleo había sido el pilar fundamental del fisco mexicano, en tanto de este sector se recauda más de la tercera parte de sus ingresos, tendencia reforzada por otras deficiencias del sistema. La actual reforma se encuentra lejos de revertir tal "petrolización" de las finanzas públicas. En concreto, los ingresos fiscales que se obtienen en virtud de las distintas actividades del rubro, han cambiado en la clasificación de sus componentes pero sin disminuir el monto lo que se prevé sea su aportación $( \pm 30 \%)$ al total de los ingresos federales en el 2015. Más detalles en http://ciep.mx/entrada-investigacion/ingresos-petroleros-15/ y http:// ciep.mx/entrada-investigacion/los-ingresos-petroleros-en-la-ilif-2015-una-nueva-composicion-ante-la-reforma-energetica/ con acceso el 19-06-2015.

${ }^{13}$ Contradictoriamente, el gobierno mexicano ha publicitado que la reforma estaba orientada a mejorar la competitividad de las antiguas paraestatales. Estas empresas y en particular PEMEX, han sido afectadas por una fuerte desinversión en capital fijo, infraestructuras y tecnología, problema relacionado directamente con las excesivas cargas fiscales. Este nexo desfavorable, fue motivo de un análisis publicado en la revista digital Energía a Debate, que a pesar de seguir una línea favorable a la mayor participación privada en el sector petrolero, advertía que la competitividad de PEMEX no mejoraría salvo le fueran aligeradas sus obligaciones fiscales. Artículo disponible en: http://energiaadebate.com/pemex-\%C2\%BFfalta-de-competitividad-oexcesiva-carga-tributaria/ con acceso 5-08-2015.

Por lo demás es interesante contrastar la carga fiscal que pesa sobre PEMEX, con las facilidades concedidas a las corporaciones privadas con las que tendrá que competir. Así mientras a PEMEX se le han sumado varias obligaciones para con Hacienda entre ellas la adición del pago del Impuesto sobre la Renta (ISR), a las petroleras privadas en cambio 1) no se le ha fijado un tope en las utilidades netas resultantes de la exportación (renta petrolera) que pueden apropiarse, 2) se les ha condonado el IVA y 3) se les regresaran los impuestos derivados de operaciones de riesgo como la exploración y explotación en aguas profundas, entre otros beneficios. Ver: (http://www.jornada.unam.mx/2014/08/06/politica/005n1pol con acceso 19-06-2015).

${ }^{14}$ Así lo anunciaba en términos generales el Secretario de Hacienda y Crédito Público Luis Videgaray Caso en marzo de 2015.Ver: httpcon 24-06-2015. Ya a inicios de la LXIII Legislatura durante agosto del presente año, se habla de elaborar un "presupuesto de base cero", esto significa en principio la revisión exhaustiva de todas las partidas que conforman el gasto público, y la eventual eliminación de aquellas que no se justifiquen. Ver: http://www.24-horas.mx/prioridad-en-san-lazaro-presupuesto-2016/ con acceso 21-08-2015.

${ }^{15}$ Durante el año 2015 la empresa sufrió un recorte de 62,000 millones de pesos, cantidad que equivale aproximadamente a un 17\% de su presupuesto asignado. Ver: http://ciep.mx/ajustes-en-el-gasto-publico-2015/ (con acceso 12-06-2016).

${ }^{16}$ Es preciso puntualizar que en México desde la Ley Federal de Presupuestos y Responsabilidad Hacendaria de 2006, el déficit fiscal queda reservado para situaciones excepcionales (Tello, 2015:364). De esta manera, si se reducen los ingresos fiscales, el gasto público -y con ello los programas sociales- tiene forzosamente que ajustarse. ${ }^{17}$ El último escándalo sobre el particular, llega a implicar a la Secretaría de Estado norteamericana.Ver reportaje periodístico en: http://www.jornada.unam.mx/2015/08/10/politica/002n1pol con acceso 11-08-2015.

${ }^{18}$ Denomínase de este modo a la plaza central de la Ciudad de México, de un simbolismo semejante al de Plaza de Mayo en Buenos Aires o la Plaza de Armas en Lima (nota del editor).

${ }^{19}$ Sobre la participación sindical resulta especialmente destacable la marcha acontecida el 1ro de diciembre de 2013, la cual fue convocada por la Unidad Patriótica por el Rescate de la Nación, de la cual participaba MORENA en alianza con la Coordinadora Nacional de Trabajadores de la Educación, el Sindicato Mexicano de Electricistas, el Sindicato de Trabajadores de la Universidad Nacional Autónoma de México, la Red de Transportistas de Pasajeros del Distrito Federal, la Alianza de Tranviarios de México, entre otras organizaciones.Ver: http://www.jornada.unam.mx/ultimas/2013/12/01/se-concentran-maestros-de-cnte-en-inmediaciones-del-angel-para-marchar-hacia-el-zocalo-4465.html con acceso 7-08-2015.

${ }^{20}$ Destaca en este sentido la labor del Observatorio Ciudadano de Energía (OCE), el Centro de Investigación Económica y Presupuestaria (CIEP), FUNDAR Centro de Análisis e Investigación, el Centro Mexicano de Derecho Ambiental o Greenpeace México.

${ }^{21}$ Ver: http://www.animalpolitico.com/2014/09/llega-amlo-al-senado-entregar-firmas-para-consulta-popularsobre-el-petroleo/ y http://www.elfinanciero.com.mx/politica/prd-entrega-firmas-para-consulta-popular-ala-camara-de-diputados.html con acceso 25-08-2015.

${ }^{22}$ Se juzga que la Ley de Hidrocarburos permite de modo implícito esta técnica, atribuye a las actividades del sector petrolero la mayor importancia para el "interés social y orden público", teniendo por tanto prioridad sobre otros usos del territorio. 
${ }^{23}$ La citada "Alianza..." ha protagonizado diferentes acciones a fin de conseguir la prohibición legal de la fractura hidráulica. La primera de ellas consistió en la entrega el 17 de julio de 2014 de 10 mil firmas en ambas cámaras del legislativo mexicano, exigiendo que fuera aprobada la ley específica para la prohibición del fracking, presentada por los diputados de Diputados del PRD, PT, Movimiento Ciudadano y Nueva Alianza tres meses antes. Ante los resultados infructuosos de esa iniciativa, la Alianza desarrolla en la actualidad una campaña de recolección de firmas a nivel internacional utilizando para ello la plataforma digital Avaaz. La intención es seguir presionando a los legisladores a fin de que aprueben la normativa antes mencionada.

${ }^{24} \mathrm{Un}$ reportaje sobre este tema en http://kaosenlared.net/mexico-audiencia-en-la-cidh-sobre-reformaenergetica-peticionarios-exhiben-violaciones-a-derechos-humanos/con acceso2-06- 2015.

${ }^{25}$ Existen no obstante opiniones que cuestionan el sentido de "nacionalización" que el gobierno ha atribuido a esta renegociación. Así por ejemplo el político Alberto Acosta hace notar que la renegociación de los contratos permitió reactivar acuerdos con empresas privadas que ya estaban a punto de extinguirse y abrió la puerta a que futuros gobiernos entreguen la explotación de campos maduros a empresas privadas o mixtas por decisión presidencial.Ver http://www.ipsnoticias.net/2010/07/ecuador-modifica-contratos-petroleros/ con acceso 6-08-2015. Por otra parte la Ley Reformatoria de Hidrocarburos de 2010, se pensó como un mecanismo no sólo para mejorar la participación estatal en la renta petrolera, sino para atraer inversiones necesarias para aumentar la capacidad productiva. En este sentido, los nuevos contratos de prestación de servicios no han satisfecho las aspiraciones de los inversionistas privados, y se ha tenido que recurrir a otros arreglos como los contratos de servicios específicos. Los mismos han sido especialmente utilizados a partir de la baja de los precios petroleros a finales de 2014. En la actualidad este modelo contractual se emplea para incrementar las reservas y producción de 17 bloques bajo el control de Petroamazonas. Ver: Petroamazonas EP(2014:11).

${ }^{26}$ Según datos de 2004, recabados por Guillaume Fontaine (2007: 40) en los contratos de participación el Estado se beneficiaba -como promedio- de un $26,2 \%$ del volumen producido. Otro estudio de Teodoro Bustamante y Oscar Zapata (2008: 122) afirma que -presumiblemente de 1996 a 2004- la participación del Estado osciló en torno al $24 \%$.

${ }^{27}$ Una revisión exhaustiva sobre el conflictivo proceso de renegociación de los contratos petroleros, así como sobre las características de la nueva fórmula de "prestación de servicios" en Orozco Medina (2012), investigación de la cual se toman las principales referencias sobre el particular salvo que se indique lo contrario.

${ }^{28}$ Según las cifras del Banco Central de Ecuador (BCE), disponibles desde http://www.bce.fin.ec/index.php/ hidrocarburos con acceso 6-08-2015, en enero de 2008 la producción petrolera a cargo de compañías públicas era el 51\% del total. Para enero de 2015, este porcentaje había alcanzado el 77\% del total.

${ }^{29}$ En el Boletín Anuario No. 36 del BCE, disponible desde internet en http://contenido.bce.fin.ec/documentos/PublicacionesNotas/Catalogo/Anuario/Boletinanuario.htm con acceso 8-09-2015), se reporta que los ingresos petroleros percibidos por el sector público han experimentado un crecimiento importante de 2006 a 2013, esto es, a razón de un 30\% anual, si bien con oscilaciones. Específicamente en 2010 estos sumaron los 7.945 millones de dólares, para alcanzar en 2011 (a un año de vigencia de la ley reformatoria de los Hidrocarburos) los 12.934 millones de dólares, en 2012 sumaron 12.219 millones, mientras en 2013 alcanzaron 11.433 millones (el reporte señala estos montos como cifras provisionales). Aunque parte de ese aumento es atribuible al alza de los precios petroleros, es innegable que un componente importante del alza en los ingresos se debe a los nuevos acuerdos contractuales firmados con las privadas y a la expansión de la producción petrolera a cargo de las empresas públicas. El aumento de los volúmenes de producción de las empresas públicas es notorio, así en el Reporte del Sector Petrolero del IV Trimestre de 2014 emitido por el BCE, se detalla que en 2007 estas producían 94 millones de barriles anuales (mdb), para pasar a $158 \mathrm{mbd}$ en 2014. Disponible desde http://contenido. bce.fin.ec/documentos/Estadisticas/Hidrocarburos/ASP201412.pdf con acceso 17-09-2015. Esta expansión de la capacidad productiva sería impensable sin una fuerte inversión pública.

${ }^{30}$ Según indicadores del Banco Central de Ecuador, se ha producido un incremento sostenido del gasto público total que de ser el $23.8 \%$ del PIB en el 2006, llegaría a un pico del 48.8\% en 2011, siendo probable que sus niveles se hayan mantenido en los años subsiguientes por encima del $40 \%$ del PIB. Reporte disponible desde internet http://contenido.bce.fin.ec/documentos/Estadisticas/SectorFiscal/OperacionesSPNF/ OperSPNF_PIB_1983_2010.xls con acceso el 6-08-2015. Este incremento sitúa al país entre los Estados más destacados del continente en materia de gasto público.

${ }^{31}$ Es probable que de 2007 a la fecha, la redistribución por la vía salarial haya aumentado, lo cual sería coherente no sólo con el crecimiento de los niveles de empleo, sino además con la elevación lenta pero progresiva del salario básico unificado. Aunque no es posible determinar la distribución real de los ingresos monetarios obtenidos por la vía salarial, pues la herramienta más adecuada para analizar la esta fluctuación, la Encuesta Nacional de Ingresos y Gastos de los Hogares Urbanos y Rurales del INEC, no se realiza con una periodicidad que permita establecer una serie histórica sobre el particular. 
${ }^{32}$ La División de Desarrollo Social de la CEPAL señala que el gasto público específicamente social casi se ha duplicado del 2006 al 2011, pasando a ser de un 4.7\% a un 8\% del PIB.Ver: http://dds.cepal.org/gasto/ indicadores/ficha/?indicador_id=28 con acceso el 6-08-2015.

${ }_{33}$ Denominación del movimiento político-social en el que se apoya el gobierno del presidente Correa (nota del editor).

${ }^{34}$ Según cifras recogidas en Ruiz e Iturralde, 2013: 86-87 en 2006, el presupuesto destinado al subsidio del GLP alcanzó los 542 millones de dólares, para alcanzar picos de 698 millones en 2007 y 2008, mientras en 2011 se mantenía sobre los 638 millones.

${ }^{35}$ Expresión emitida en un conversatorio entre investigadores de la región, sostenido en el marco del III Congreso Latinoamericano de Flacso, celebrado en Quito del 26 al 28 de agosto de 2015.

${ }^{36}$ En este punto coincidimos con una de las tesis de Magali Marega (2015).

${ }^{37}$ En este sentido, nos parecen relevantes las palabras del ex sindicalista petrolero Diego Cano (2009:293), quien por una parte afirma que la acción de estas corporaciones fue clave para resistir a los distintos gobiernos neoliberales, pero al mismo tiempo señala que "una vez que se alcanzó cierta protección y estabilidad para los trabajadores, se creó una quimera de conformidad y satisfacción, acompañada de la pérdida de conciencia de clase, apatía y desmovilización". A partir de tales argumentos es posible inferir que tales organizaciones habían perdido parte de su legitimidad ante la ciudadanía, proceso que no puede atribuirse en exclusiva a las campañas difamatorias alineadas con la Patronal o con el propio Estado.

${ }^{38}$ De hecho, estas características de las "conquistas sindicales" son fáciles de percibir si se revisan los mandatos constituyentes de 2007 que intentaron regularlas. Así, utilizando la información -pero no el enfoque- proporcionada por Diego Cano (2009: 296-298), el mandato No. 2 establecía un límite de 24 salarios Básicos Unificados (5.760 Usd) como remuneración mensual máxima del sector público. Por otra parte, el Mandato No. 4 precisó que no superarían los 300 salarios Básicos Unificados (72.000 u\$s) las indemnizaciones por renuncia voluntaria, supresión de partida o retiro voluntario para acogerse a la jubilación de todos los servidores públicos, con excepción de los pertenecientes a las Fuerzas Armadas y la Policía. Finalmente en la Disposición Transitoria tercera del Mandato No.8, se dispuso la polémica revisión de todos los contratos colectivos del sector público a fin de restringir las cláusulas que permitían por ejemplo la transferencia y transmisión de cargos a familiares, o el cobro por dirigentes laborales de horas suplementarias y extraordinarias no trabajadas. ${ }^{39}$ En este sentido, un primer antecedente lo constituyó la intención de revisar los convenios colectivos, planteada ya desde los mandatos de la Asamblea Constituyente de 2007-2008. En la propia Constitución aprobada, se introdujo la distinción entre "servidores" y obreros "públicos" (art. 229) que ha ido encaminada a debilitar el sindicalismo en el sector público. Otras avanzadas en este sentido estarían dadas por la entrada en vigor de la Ley Orgánica de Empresas Públicas (LOEP) de 2009 y la Ley Orgánica del Servicio Público (LOSEO) de 2010, como se verá poco más adelante. Ulteriores debates se han dado en todo a la presentación por el gobierno de un nuevo proyecto de Código Orgánico de Relaciones Laborales (CORL)en mayo de 2014. Un resumen sobre las principales objeciones al particular en Paz y Miño Cepeda, 2014, quien destaca la sustitución del esquema de jubilación patronal por un bono, la desatención al trabajo precario en el sector público y la limitación del derecho a huelga, entre otras cuestiones. Es de destacar que tal propuesta ha quedado en suspenso, y hasta el presente sólo se ha aprobado la Ley para la Justicia Laboral y Reconocimiento del Trabajo en el Hogar (2015) que reforma el código laboral vigente desde 1938 pero sin inmiscuirse en ninguno de los puntos candentes del CORL.

${ }^{40}$ A pesar de la clara movilización pro-gubernamental de la CUT, explícita en las convocatorias publicadas en su web institucional (http://cut.org.ec/) no es posible concluir que esta organización haya alcanzado posicionarse como un poder corporativo, como lo evidencia la escasa relevancia política de sus dirigentes o su incapacidad para hacer avanzar un proyecto alternativo de reformas al Código Laboral.

${ }^{41}$ Particularmente relevante parece el acuerdo alcanzado el pasado 20 de agosto de 2015 entre la CUT y el Parlamento Obrero con la Subcomisión de Derechos de los Trabajadores de la Asamblea Nacional, encaminados a revertir las enmiendas constitucionales promovidas por el Presidente, las cuales afectarían temas como el derecho de sindicalización y de negociación colectiva para los servidores públicos.Ver: http://ecuatorianoenvivo.com/se-alcanza-acuerdo-entre-la-asamblea-y-central-unitaria-de-trabajadores/ con acceso 14-10-2015. ${ }^{42}$ Según cifras del censo económico de 2010 elaborado por el INEC, el 94\% de los establecimientos económicos ecuatorianos tiene entre 1 y 9 trabajadores.

${ }^{43}$ Según el informe Indicadores Laborales (INEC, 2015), de junio de 2010 a junio de 2015, los trabajadores informales representaban como promedio el $41 \%$ de los ocupados a nivel nacional. Asimismo, precisa que a junio de 2015 la fuerza de trabajo empleada en el sector de las manufacturas representa sólo un 11\% del total, mientras que los transportistas suman apenas un $6 \%$. Los sectores que mayor número de empleo concentran son la agro-ganadería, la silvicultura y la pesca (27\%), así como el comercio (18\%). 


\begin{abstract}
${ }^{44}$ Según reportaron los diarios, sólo 359.761 firmas fueron declaradas válidas por el CNE.Ver: http://www.telegrafo.com.ec/politica/item/yasunidos-no-alcanza-firmas-para-consulta-popular-sobre-yasuni.html y http:// www.elcomercio.com/actualidad/politica/firmas-recolectadas-yasunidos-no-alcanzan.html con acceso el 1810-2015. Aun tomando esta cifra como referencia, tendríamos que aproximadamente el $2 \%$ de la población ecuatoriana respaldaba la realización de una consulta popular sobre el tema, indicador que señala una magnitud si bien minoritaria, ya significativa de que la decisión presidencial no gozaba de una aprobación indiscutida.

${ }^{45}$ No obstante, es preciso reconocer que no hay una homogeneidad total respecto a la actitud frente al gobierno por parte de estos movimientos. Así por ejemplo, en la decisión de intensificar la actividad petrolera ampliando las explotaciones en los territorios amazónicos del ITT el gobierno ha conseguido incluso ser respaldado por la etnia Waorani, cuyos miembros esperan recibir a cambio atención a sus reivindicaciones. Ver el reporte: http://internacional.elpais.com/internacional/2013/09/18/actualidad/1379477347_009394. html con acceso 6-08-2015.

${ }^{46}$ La reciente polémica desatada en torno a la concesión de una licencia ambiental para explotar otro bloque dentro delYasuní (el bloque 55 o campo Armadillo), donde se presume la existencia de poblaciones indígenas no contactadas, demuestra que las tensiones se mantienen vigentes. Ver sobre el particular, la carta abierta que dirigió el colectivo Yasunidos al Presidente Ecuatoriano el pasado 12 de octubre de 2015. Disponible desde internet http://sitio.yasunidos.org/es/comunicacion/blog/209-carta-abierta-por-la-proteccion-de-los-pueblos-tagaeri-y-taromenane.html con acceso 15-10-2015.

${ }^{47}$ A pesar de que la mejora en la participación de la renta petrolera, le ha permitido al Estado utilizar la inversión pública para impulsar la reactivación productiva del país, este proceso no ha desembocado en una dinamización del sector industrial. Si se analiza el ritmo de crecimiento anual del sector manufacturero de 2007 a 2013, este arroja una tasa promedio de 4.3\%. Sin embargo, resulta más dinámico el crecimiento del sector agro-ganadero y pesquero $(11,6 \%)$, de la construcción $(7.7 \%)$ o de las actividades de intermediación financiera (6.4\%). Cálculos basados en el reporte del BCE sobre el PIB por rama de actividad. Disponible en:contenido.bce.fin.ec/documentos/PublicacionesNotas/Catalogo/IEMensual/m1962/IEM-432.xlsx con acceso 17-09-2015. En la nota No. 4 se hizo referencia al comportamiento de las importaciones ecuatorianas. ${ }^{48}$ Según la información publicada por el Banco Central de Ecuador, todavía en 2014 los Estados Unidos eran el principal receptor de las exportaciones ecuatorianas (por valor de más de 11 mil millones de dólares). En segundo lugar quedarían los países pertenecientes a la Asociación Latinoamericana de Integración (7.300 millones), luego los países de la Unión Europea (casi 4 mil millones) y por último Asia (casi 2.500 millones). Ver: http://contenido.bce.fin.ec/home1/estadisticas/bolmensual/IEMensual.jsp con acceso 25-08-2018 Se discute actualmente sobre la presencia cada vez más importante de China no sólo como mercado de las exportaciones ecuatorianas -especialmente las petroleras- sino como origen de múltiples créditos al país, por la vía de los contratos de venta anticipada de petróleo. Determinar si tales contratos constituyen en realidad mecanismos de endeudamiento público es una cuestión que permanece poco esclarecida, fundamentalmente porque los detalles de los mismos no han sido de conocimiento público.
\end{abstract}




\section{Referencias}

Auty, R. (1993) Sustaining development in mineral economies: the Resource Curse Thesis, Londres, Routledge.

Barrera, M. A. (2011) "Rediscutiendo el populismo: apuntes y reflexiones en torno de su capacidad explicativa”. Intersticios. Revista Sociológica de Pensamiento Crítico [Online], Vol.5. Dirección URL: http://www.intersticios.es/article/view/8492/6244 [Con acceso $18-08-2015]$.

Bensusán, G. y J. Middlebrook (2013) Sindicatos y política en México: cambios, continuidades y contradicciones. México DF: FLACSO México/UAM-Xochimilco/ CLACSO.

Borón,Atilio (2011) “¿Una nueva era populista en América Latina?”. En A.Borón, Sujeto y Conflicto en la Teoría Política. Buenos Aires: Ediciones Luxemburg. [Online] Dirección URL: https://docs.google.com/file/d/0Bx2YC3gJbq2TMjkteV82N2t0SUU/edit [Con acceso 12-08-2015].

Bustamante, T. y O. Zapata (2008). Características de los contratos petroleros. Dirección URL: http://www.flacsoandes.edu.ec/biblio/catalog/resGet.php?resId=13245 [Con acceso 4-09-2015].

Cano, D. (2009). "Regresión laboral en el Ecuador y sus consecuencias: gobierno de Rafael Correa”. En Programa Andino de Derechos Humanos (ed.) ¿Estado constitucional de Derechos? Informe sobre derechos humanos Ecuador 2009. Quito: Universidad Andina Simón Bolívar Sede Ecuador: Ediciones Abya-Yala: 291-314

Cypher, J. M. y Y. Alfaro, (2016) “Triángulo del neodesarrollismo en Ecuador". Revista Problemas del Desarrollo [Online]. Dirección URL: http://probdes.iiec.unam.mx/ numeroenpdf/185_v47/07art_Cypher.pdf [Con acceso 5-04-2016].

De la Torre, Carlos (2010) "Rafael Correa un Populista del Siglo XXI" [Online] Dirección URL: http://lanic.utexas.edu/project/etext/llilas/vrp/delatorre.pdf [Con acceso 19-08-2015].

Fontaine, G. (2007) "Gobernanza energética, renta petrolera y conflictos en el Ecuador”. En Ecuador a Debate [Online]. Dirección URL: http://www.researchgate. net/publication/258048104 [Con acceso 5-09-2015].

Fontaine, G. (2010) Petropolítica. Una teoría de la gobernanza energética, Quito, FLACSO. 
Herrera-Revelo, S. G. (2016) "La lucha por la tierra no es sólo una lucha por el bienestar campesino, sino que es la lucha por una sociedad democrática y moderna: Stalin Herrera”. En Salcedo, I Blog la LINEA DE FUEGO. [Online]. Dirección URL: http:// lalineadefuego.info/2016/01/05/la-lucha-por-la-tierra-no-es-solo-una-lucha-por-elbienestar-campesino-sino-que-es-la-lucha-historica-por-la-construccion-de-una-sociedad-democratica-y-moderna-stalin-herrera/ [Con acceso 6-04-2016].

Instituto Nacional de Estadísticas y Censos, (2015) Indicadores Laborales, Junio. [Online]. Dirección URL: http://www.ecuadorencifras.gob.ec/documentos/webinec/EMPLEO/2015/Junio-2015/Informe_economia_laboral-jun15.pdf [Con acceso 17-09-2015].

Laclau, Ernesto (2005). La razón populista, Buenos Aires, Fondo de Cultura Económica.

Lynch, Nicolás (2000) "Neopopulismo: un concepto vacío”. En Lynch, N. (ed.) Política y antipolítica en el Perú. Lima: DESCO: 153-179.

Marega, M. (2015) "Reconfiguración de la relación Estado-sindicalismo petrolero público en el Ecuador de la Revolución Ciudadana". Ecuador a Debate [Online]. Dirección URL: http://repositorio.flacsoandes.edu.ec/bitstream/10469/7534/2/REXTN-ED94. pdf [Con acceso 08-09-2015].

Minteguiaga, A. y Ubasart-González, G. (2014) "Menos mercado, igual familia. Bienestar y cuidados en el Ecuador de la Revolución Ciudadana”. Íconos. Revista de Ciencias Sociales [Online]. Dirección URL: http://revistas.flacsoandes.edu.ec/index. $\mathrm{php/iconos/article/viewFile/1430/1215} \mathrm{[Con} \mathrm{acceso} \mathrm{15-09-2015].}$

Orozco Medina, M. C. (2012). Una política sin rumbo: el caso de la política petrolera ecuatoriana 2005-2010. Tesis de Maestría, FLACSO Ecuador.

Ospina Peralta, Pablo (2015) “¿Por qué protestan en Ecuador? Rafael Correa y el fracasado aumento del impuesto a las herencias". Revista Nueva Sociedad [Online]. Dirección URL: http://nuso.org/media/articles/downloads/7.TC_Ospina_258.pdf [Con acceso 19-05-2015].

Paz y Miño Cepeda, J. J. (2014) “Trabajadores y código laboral”. La línea de fuego [Online]. Dirección URL: http://lalineadefuego.info/2014/06/25/trabajadores-y-codigo-laboral-por-juan-j-paz-y-mino-cepeda/ [Con acceso 14-10-2015]. 
PETROAMAZONAS EP (2014) Informe de Gestión. [Online]. Dirección URL: http:// www.petroamazonas.gob.ec/wp-content/uploads/downloads/2015/03/INFORMEPAM-2014-para-web.pdf [Con acceso 17-09-2015].

Portantiero, Juan Carlos y Miguel Murmis (1971) Estudios sobre los orígenes del peronismo, Buenos Aires, Siglo XXI Editores.

Ramírez Gallegos, Francisco (2010). "Fragmentación, reflujo y desconcierto. Movimientos sociales y cambio político en el Ecuador (2000-2010)”. OSAL [Online]. Dirección URL: http://biblioteca.clacso.edu.ar/ar/libros/osal/osal28/04Ramirez.pdf [Con acceso 23-04-2015].

Ross, M. (2003) “The Natural Resource Curse: how wealth can make you poor”. Natural Resources and violent conflicts: options and action. Washington D.C.:World Bank:17-42

Ruiz, M. e Iturralde, P. (2013). La alquimia de la riqueza. Estado, petróleo y patrón de acumulación en Ecuador, Quito, CDES.

Svampa, Maristela (2015) “Termina la era de las promesas andinas”. [Online]. Dirección URL: http://www.revistaenie.clarin.com/ideas/Termina-promesas-andinas_0_1417058291. html [Con acceso 2-09-2015].

Tello, Carlos (2015) La economía política de las finanzas públicas: México 1917-2014, México, Facultad de Economía, UNAM.

Vilas, Carlos M. (2011). “Populismo y democracia en América Latina: convergencias y disonancias". En C.M.Vilas, Después del neoliberalismo: estado y procesos políticos en América Latina. Remedios de Escalada: Ediciones de la UNLa:165-188.

\section{Cómo citar este artículo}

García Chediak, Rosa: ¿Populismo petrolero? Experiencias recientes en México y Ecuador. Revista Perspectivas de Políticas Públicas (2016) Vol. 6, N 11: 121-146. 